\title{
Supplier integration and firm performance: The moderating effects of internal integration and trust
}

\begin{abstract}
This study proposes and empirically tests a model of the moderating effects of internal integration and trust on the impacts of information, process and strategic integration with suppliers on firm performance using structural equation modelling and data collected from 261 manufacturing firms in Vietnam. The results show that all three types of supplier integration positively associate with firm performance. Internal integration enhances the impact of process integration with suppliers on firm performance, but does not moderate the impacts of information and strategic integration with suppliers. Internal trust has insignificant, positive and negative influences on the effects of information, process and strategic integration with suppliers on firm performance. The findings show that internal integration and trust play different roles in moderating the positive effects of information, process and strategic integration with suppliers on firm performance, which elucidates a possible reason for previous mixed findings on the relationship between supplier integration and firm performance.
\end{abstract}

Key words: supplier integration, internal integration, internal trust, firm performance

\section{Introduction}

A manufacturer can integrate with suppliers by strategically cooperating with them and collaboratively managing inter-organization processes (Flynn, Huo, and Zhao 2010). Supplier integration aims to improve the efficiency and effectiveness of the information and physical flows between a manufacturer and suppliers, which can lead to seamless processes and cohesive supply networks that cannot be easily matched by competitors (Yeung et al. 2009; Lai et al. 2012; Zhao et al. 2013). Although a growing body of studies suggests that higher levels of supplier integration lead to greater potential benefits (Frohlich and Westbrook 2001; Huo 2012; Alfalla-Luque, MedinaLopez, and Dey 2013; Moyano-Fuentes, Sacristán-Díaz, and Garrido-Vega 2016), some empirical studies fail to establish a positive relationship between supplier 
integration and performance outcomes (Swink, Narasimhan, and Wang 2007; Flynn, Huo, and Zhao 2010; Lai et al. 2012; Zhao et al. 2013).

Researchers argue that a firm may integrate with suppliers at operational and/or strategic levels (Stank, Daugherty, and Ellinger 1999; Swink, Narasimhan, and Wang 2007; Alfalla-Luque, Medina-Lopez, and Dey 2013; Yu 2015), which may influence performance in different ways. Failing to identify the distinctive effects of different types of supplier integration on firm performance may be one reason for the inconsistent findings (Flynn, Huo, and Zhao 2010; Zhao et al. 2013). Therefore, empirically investigating the individual effects of information, process and strategic integration with suppliers can extend current knowledge on the mechanisms through which supplier integration improves firm performance.

Contingencies may be another reason for the mixed findings on the relationship between supplier integration and firm performance (Wong, Boon-itt, and Wong 2011; Lai et al. 2012; Huo et al. 2014). Researchers argue that internal integration positively influences supplier integration (Zhao et al. 2011; Lai et al. 2012; Moyano-Fuentes, Sacristán-Díaz, and Garrido-Vega 2016) and that they are complementary for improving performance (Germain and Iyer 2006; Schoenherr and Swink 2012). Hence, empirically investigating the impacts of internal integration on information, process and strategic integration with suppliers and their interaction effects on firm performance can enhance existing knowledge on how internal and supplier integration jointly affect firm performance (Flynn, Huo, and Zhao 2010). In addition, although researchers argue that trust among employees plays critical roles for a firm to absorb and use external knowledge and resources (Morgan and Hunt 1994; Adler and Kwon 2002), few prior studies have examined how internal trust influences the relationship between supplier integration and firm performance. Therefore, the findings on the moderating roles of internal integration and trust can help managers develop processes to enhance the value of supplier integration.

Vietnam is experiencing high speed economic growth. Vietnamese manufacturers are also becoming increasingly important within global supply chains (Kumar, Medina, and Nelson 2009). According to the World Bank, Vietnam's annual GDP growth was $6.4 \%$ and exports of goods and services accounted for 72\% of GDP in 2010. Vietnamese manufacturers are gradually taking business from China because of increasing land and labour costs in China and the appreciation of the Chinese Yuan (The Flying Factory 2014). A 'China plus one' strategy has gained popularity in 
multinationals (Kumar, Medina, and Nelson 2009). As a result, Vietnam is now playing an active role in 'Factory Asia' and has become an integrated part of the East Asian production network (The Flying Factory 2014). In addition, Vietnam has a specific cultural environment which may influence the impact of supplier integration on firm performance (Hofstede, Hofstede, and Minkov 2010). Hence, empirically investigating the joint effects of supplier integration and internal integration and trust on firm performance can not only validate existing findings about supplier integration in Vietnam but also help multinationals optimise their global supply chains to boost productivity.

The objective of this study is to empirically explore how internal integration and trust affect the impact of supplier integration on firm performance. The study addresses three research questions. First, what are the individual effects of information, process and strategic integration with suppliers on firm performance? Second, how does internal integration influence the effects? Third, how does internal trust influence the effects? This study contributes to operations management literature by providing empirical evidence that information, process and strategic integration with suppliers are positively associated with firm performance and that the relationships are contingent on internal integration and trust, which have not been adequately addressed in prior research. The results show that internal trust increases process integration's but decreases strategic integration's impacts on firm performance and that internal integration only enhances the impact of process integration on firm performance, which provide a possible explanation for the inconsistent findings about the relationship between supplier integration and firm performance (Dröge, Jayaram, and Vickery 2004; Flynn, Huo, and Zhao 2010; Schoenherr and Swink 2012; Zhao et al. 2013; Huo et al. 2014). In addition, this study generalises the findings that internal and supplier integration enhance firm performance in Vietnam. The results can also provide managerial guidelines for executives on how to integrate with suppliers and how to fully reap the benefits of supplier integration on firm performance by developing internal practices and systems.

\section{Literature review and research hypotheses}

\subsection{Supplier integration}

Supplier integration occurs when a firm partners with its suppliers to structure inter-organisational strategies, develop synchronised processes and share information 
and knowledge (Flynn, Huo, and Zhao 2010). It has been considered to be a critical source of competitive advantage as it improves inter-enterprise operations (Stank, Daugherty, and Ellinger 1999; Wang, Yeung, and Zhang 2011). Supplier integration provides a unity of effort in meeting customer requirements for products (Narasimhan and Kim 2002) and in responding to changes in markets (Zhao et al. 2013). Firms can acquire insights into suppliers' processes, capabilities and constraints (Yeung et al. 2009; Huo 2012), ultimately enabling more effective planning and forecasting, better product and process designs and reduced transaction costs (Zhang and Huo 2013). A firm may collaborate with suppliers through enterprise integration and/or interoperability (Panetto and Moline 2008). Enterprise integration focuses on interenterprise long-term collaboration and on the homogenisation, coherence, interdependency and standardisation of models, methods, terms, tools and applications among enterprises, and hence a firm and suppliers are tightly coupled (Chen, Doumeingts, and Vernadat 2008). Enterprise interoperability emphasises that each enterprise retains its independence and gains in its capability to collaborate and to synchronise strategies, resources, skills and processes with other enterprises, with the support of the new information and communication technologies, without changing their models, methods, languages and tools, and hence a firm and suppliers are loosely coupled (Chen, Doumeingts, and Vernadat 2008; Panetto and Moline 2008). A firm can integrate with suppliers through information sharing, process synchronisation and strategic alignment (Alfalla-Luque, Medina-Lopez, and Dey 2013; Zhang and Huo 2013).

Information integration occurs when a firm works together with suppliers to exchange information and develop a coordinated information flow and system (Panetto and Moline 2008; Yeung et al. 2009). It requires a firm and suppliers to develop interoperable systems by connecting and integrating core elements from enterprise resource planning systems, data warehouses and other enterprise applications into a common platform via computer networks (Chen, Doumeingts, and Vernadat 2008). Through the standardisation of data models and query languages, joint development of applications and direct communications with suppliers via computer networks, a firm can build performance metrics associated with task execution and outcomes and learn about critical changes in environments (Frohlich and Westbrook 2001), which allow the firm and its suppliers to coordinate production and delivery, improve forecasting and planning (Alfalla-Luque, Medina-Lopez, and Schrage 2013) and develop an 
accurate assessment of performance bottlenecks across supply chains (Paulraj and Chen 2007; Cai, Jun, and Yang 2010). Providing information (e.g. scheduling, planning, shipment notices and sales forecasting) to suppliers enables a firm to improve inventory management and replenishment planning (Lai et al. 2012), which, in turn, helps the firm reduce operating costs, transaction risks and coordination costs and improve productivity.

Process integration occurs when a firm works together with suppliers to structure and synchronise inter-organisational processes and involves its key suppliers in internal operations (Zhao et al. 2008). Collaborative planning and inventory management enable a firm to improve procurement and logistics processes and optimise supply management (Gimenez and Venture 2005). By involving suppliers in product development and improvement projects, a firm and suppliers can develop a common understanding of how to fulfil customer demands and respond to changes in markets (Schoenherr and Swink 2012). Joint decision making and problem solving facilitate a firm and suppliers to coordinate activities and synchronise processes, which help them maintain relationships, avoid possible conflict and serve customers better (Palomero and Chalmeta 2014).

Strategic integration occurs when a firm structures its strategic goals, objectives and plans, and develops and adjusts its competitive strategies jointly with suppliers (Narasimhan and Kim 2002; Swink, Narasimhan, and Wang 2007). This long-term orientation requires top management commitment and relationship-specific investments (Zhao et al. 2011). Strategic integration provides a blueprint for supply management (Huo 2012) and creates a win-win relationship for achieving mutually beneficial strategic goals (Johnson 1999). Involving suppliers in strategy development allows a firm to build a strategic mind-set with regard to its supply chains (Paulraj and Chen 2007) and to explicitly consider how to integrate resources and competencies from its suppliers (Johnson 1999). Adjusting strategies in response to its suppliers enables a firm to reflect environmental changes in performance targets and design and execute optimal responses quickly (Alfalla-Luque, Medina-Lopez, and Dey 2013). The firm can then better meet customer requirements and capture new opportunities by leveraging suppliers' resources and capabilities (Schoenherr and Swink 2012).

\subsection{Internal integration and trust}

We focus on the integration and trust between purchasing and production departments in this study as they are predominantly responsible for the upstream 
activities of a supply chain and have considerable opportunities to interact with suppliers compared with other departments within a firm. Internal integration happens when a firm structures the practices, procedures and behaviour of its functional departments into integrated and synchronised processes to fulfil customer requirements (Zhao et al. 2011). Internal integration facilitates the translation of production demands into purchasing specifications and improves material movements and ordering processes (Palomero and Chalmeta 2014). Through scheduled interdepartmental meetings or casual contacts, purchasing and production employees can exchange information and performance feedback (Paulraj and Chen 2007). The use of crossfunctional teams also enables purchasing and production departments to make joint decisions (Swink, Narasimhan, and Wang 2007). Internal integration connects functional departments (Lai et al. 2012) and facilitates information and physical flows (Dröge, Jayaram, and Vickery 2004). Hence, internal integration has been identified as an important approach that helps firms develop their capabilities (Swink, Narasimhan, and Wang 2007; Zhao et al. 2011).

Trust can be defined as 'the extent to which a person is confident in, and willing to act on the basis of, the words, actions and decisions of another' (McAllister 1995, 25). Rooted in emotional attachment and the care and concern for others' welfare (Mayer, Davis, and Schoorman 1995), internal trust indicates harmony and commitment between production and purchasing employees. It reflects that employees appreciate each other's roles and there are compatible purposes and goals between the two departments (Le Meunier-FitzHugh and Piercy 2007). Internal trust also indicates benevolence and goodwill (McAllister 1995), which can establish a basis for intimacy and reliability between employees and thus reduce opportunism and the dependence on rigid monitoring and control systems for cross-functional coordination (Zaheer, McEvily, and Perrone 1998; Bunduchi 2013).

\subsection{The effect of internal integration on supplier integration}

Integration between production and purchasing departments forms a basis for information integration with suppliers (Lai et al. 2012), as it is difficult for a firm to communicate and exchange information with suppliers if its internal units are acting within functional silos (Paulraj and Chen 2007; Moyano-Fuentes, Sacristán-Díaz, and Garrido-Vega 2016). Internal integration increases the accuracy and timeliness of the information flow and the visibility of the firm, which enhance suppliers' understandings of the needs of the firm, especially regarding the specifications and standards of raw 
materials and components (Williams et al. 2013). Joint planning and decision making also assist employees to identify critical issues, events or changes that may affect suppliers, improving the quality and quantity of information sharing (Swink, Narasimhan, and Wang 2007; Zhao et al. 2011). Therefore, we propose the following hypothesis.

Hla: Internal integration positively associates with information integration with suppliers.

If production and purchasing departments are not well integrated, processes within a firm will be fragmented and disconnected (Yeung et al. 2009; Yu 2015). This makes it difficult for suppliers to coordinate production planning and inventory management with the firm and to participate in product development and problem solving activities (Zhao et al. 2011). Through information sharing and joint planning, internal integration aligns the activities between production and purchasing departments and allows the two departments to develop common expectations and agreed objectives. Cross-functional teams enhance a firm's capability to prevent potential conflict and eliminate redundancies and barriers during process integration with suppliers (Moyano-Fuentes, Sacristán-Díaz, and Garrido-Vega 2016). Integration between production and purchasing departments thus provides a well-functioning interface that facilitates the firm to coordinate processes and work together with suppliers (Alfalla-Luque, MedinaLopez, and Schrage 2013). Therefore, we propose the following hypothesis.

H1b: Internal integration positively associates with process integration with suppliers.

Internal integration ensures that production and purchasing departments have compatible goals and objectives for supply management (Johnson 1999) and enables employees to develop consistent expectations from suppliers, including material specifications and costs, planning, scheduling and delivery (Yu 2015). These enable the firm to maintain good relationships with key suppliers (Cai, Jun, and Yang 2010) and to consider their interests when developing strategies (Zhao et al. 2011). Joint decision making and information sharing ensure that there is a common understanding between employees of the firm's strategic plans and the suppliers' roles in the firm's strategies (Huo 2012). This builds a foundation for employees to approach key suppliers and involve them in developing business strategies. Internal integration can also avoid misunderstandings between internal functions (Wong, Boon-itt, and Wong 2011), 
reducing a supplier's risks associated with strategic partnership (Zhang and Huo 2013; Zhao et al. 2013). Therefore, we propose the following hypothesis.

H1c: Internal integration positively associates with strategic integration with suppliers.

\subsection{The effect of supplier integration on firm performance}

Firm performance refers to how well a firm achieves its market-oriented and financial goals ( $\mathrm{Li}$ et al. 2006). It evaluates the firm's profitability and market growth (Huo et al. 2014) and is viewed as the final performance outcome (Huo 2012). Financial and market criteria provide a useful tool to assess a firm's links with suppliers, internal functions and all external and internal processes over time (Li et al. 2006; Zhao et al. 2013).

Information integration with suppliers enables a firm to obtain knowledge from suppliers, such as production scheduling and planning and inventory levels, which helps the firm optimise inter-organisational processes (Zhao et al. 2013; Zhang and Huo 2013). Direct communications and frequent information exchange improve supply chain transparency and visibility, which reduce the uncertainty and complexity during integration and facilitate measurement and management processes in long-term supply networks (Williams et al. 2013). Information integration can reduce the costs of gathering information about a supply network and allow a firm to identify capable suppliers and evaluate supplier performance. Information integration also improves suppliers' understandings of a firm's needs about products and services, which help them better meet the firm's changing requirements (Huo 2012). Suppliers can then achieve a high level of customer service, which, in turn, improves the firm's performance (Flynn, Huo, and Zhao 2010). Therefore, we propose the following hypothesis.

H2a: Information integration with suppliers positively associates with firm performance.

Process integration with suppliers can create synchronised processes across a supply chain (Frohlich and Westbrook 2001). It seeks to bring suppliers into a firm's internal operations (Flynn, Huo, and Zhao 2010) and provides opportunities to improve transactional efficiencies, solve problems and identify new product ideas. Involving suppliers in product development, production planning and project teams enables a firm and suppliers to coordinate business decisions (Lai et al. 2012), which reduces production lead times and speeds up new product introduction and delivery (Yu 2015). 
Joint problem solving with suppliers increases responsiveness to customer demands and reduces operating costs (Huo 2012). The firm can also develop a better understanding of its suppliers, which reduces uncertainty and risks. Process integration with suppliers can achieve operating synergies and higher levels of efficiency, enhancing firm performance. Therefore, we propose the following hypothesis.

H2b: Process integration with suppliers positively associates with firm performance.

Strategic integration with suppliers can help a firm reduce inter-organisational conflict by aligning targets and objectives (Le Meunier-FitzHugh and Piercy 2007). Involving suppliers in strategic planning ensures that there are congruent goals between supply chain partners (Wang, Yeung, and Zhang 2011), which builds a foundation for creating and sustaining relationships and for establishing a compatible technological trajectory. Suppliers will perform according to the agreement and fulfil their obligations since this is also in their interests (Yeung et al. 2009). Strategic interdependence and common goals can greatly reduce opportunistic behaviour and risks within supply chains, minimise production and transaction costs and facilitate relationship-specific investments (Zhao et al. 2008). Strategic integration also enables a firm to leverage supply chain resources and knowledge (Hult, Ketchen Jr., and Slater 2004) and to detect and respond to critical changes in supply chains collaboratively with suppliers (Swink, Narasimhan, and Wang 2007; Schoenherr and Swink 2012), reducing supply uncertainty. Therefore, we propose the following hypothesis.

H2c: Strategic integration with suppliers positively associates with firm performance.

\subsection{The effect of internal integration on firm performance}

Through information sharing and joint planning, internal integration strategically links up production and purchasing departments and aligns their activities (Gimenez and Venture 2005; Schoenherr and Swink 2012). It enables production and purchasing departments to operate as part of a connected and integrated process and employees to optimise operations at the firm level (Yu 2015). Common goals and joint decision making allow a firm to respond to marketplace changes and production disruptions quickly, which reduce total costs and lead times and improve process flexibility. Integration between production and purchasing departments can also speed up supplier selection, evaluation and development, decrease supply uncertainty, improve production and logistics planning, reduce inventory obsolescence and ensure that the 
supply chain is efficient and responsive, which improve firm performance (Narasimhan and Kim 2002; Dröge, Jayaram, and Vickery 2004; Zhang and Huo 2013). Therefore, we propose the following hypothesis.

H3: Internal integration positively associates with firm performance.

\subsection{The effect of internal trust on internal integration}

Trust is a useful lubricant and fundamental ingredient in maintaining integration and avoiding conflict between purchasing and production staff (Cai, Jun, and Yang 2010). When an employee trusts a colleague, he/she believes that the colleague will not take advantage of him/her (McAllister 1995). Trust therefore increases employees' confidence in working together and making joint decisions, and motivates them to pursue goals collectively (Morgan and Hunt 1994; Yeung et al. 2009). Trust also increases behaviour transparency and employees believe their knowledge will be used for good purposes (Mayer, Davis, and Schoorman 1995). It improves the volume, diversity and richness of the information flow between production and purchasing departments (Adler and Kwon 2002). Hence, it creates an atmosphere in which employees in production and purchasing departments are more likely to share strategic plans and performance feedback in an accurate and timely manner. Therefore, we propose the following hypothesis.

H4: Internal trust positively associates with internal integration.

\subsection{The effect of internal trust on firm performance}

Trust between production and purchasing departments can prevent opportunistic behaviours and decrease the perception of risks and uncertainty (Adler and Kwon 2002; Wang, Yeung, and Zhang 2011), reducing costs for internal monitoring and control (Mayer, Davis, and Schoorman 1995). Internal trust facilitates employees to align goals and objectives which promotes employees to make joint decisions and adjust purchasing and production operations to respond to changes in environments quickly (Yeung et al. 2009), improving process flexibility and responsiveness. A lack of trust may lead to conflict among employees, decreasing the efficiency and speed of production scheduling and planning (Adler and Kwon 2002; Cai, Jun, and Yang 2010). Trust can also create strong social norms and beliefs that motivate employees to create new knowledge and new applications of existing knowledge together, which help a firm develop new products and processes, increasing firm performance (Zaheer, McEvily, and Perrone 1998; Wang, Yeung, and Zhang 2011). Therefore, we propose the following hypothesis. 
H5: Internal trust positively associates with firm performance.

\subsection{The moderating effect of internal integration}

Internal integration provides a mechanism through which the employees in production and purchasing departments can work together and develop a sense of belonging (Zhao et al. 2011). They are thus more willing to share private and privileged information with each other, seek consensus in decision making and invest in lateral communication channels (Yeung et al. 2009). Internal integration also enables them to develop a shared meaning about the information acquired from suppliers and to absorb the information to solve problems and improve operations (Hult, Ketchen Jr., and Slater 2004; Schoenherr and Swink 2012). Internal integration thus allows a firm to take full advantage of information integration with suppliers, leading to better performance (Moyano-Fuentes, Sacristán-Díaz, and Garrido-Vega 2016). Therefore, we propose the following hypothesis.

H6a: Internal integration enhances the effect of information integration with suppliers on firm performance.

Internal integration enables employees to help each other and deal with conflict through compromise and negotiation (Zhao et al. 2011). The integration between production and purchasing departments facilitates employees to participate in joint evaluation and planning for supplier involvement in product development and process improvement projects, helping the firm use acquired suppliers' resources more effectively (Swink, Narasimhan, and Wang 2007). Internal integration plays an important role for streamlining operations and presenting opportunities for concurrent engineering and process modularity and for building a shared vison between employees (Dröge, Jayaram, and Vickery 2004; Lai et al. 2012). Process flexibility can be improved and the firm can adjust its operations to move suppliers' resources efficiently and quickly to the most appropriate internal units where the value of resources is more likely to be recognised and realised (Zhao et al. 2011). Internal integration provides a mechanism through which firms can better generate and exploit opportunities for using the resources obtained from process integration with suppliers (Frohlich and Westbrook 2001; Flynn, Huo, and Zhao 2010). Therefore, we propose the following hypothesis.

H6b: Internal integration enhances the effect of process integration with suppliers on firm performance.

Strategic integration with suppliers contributes to firm performance by developing a coordinated supply management strategy and consistent goals and beliefs (Johnson 
1999). Internal integration enables production and purchasing employees to coordinate the operationalisation and execution of such strategies and objectives by adjusting operations and future investments in technologies, equipment and training accordingly (Narasimhan and Kim 2002). Integration also prevents conflict between employees when determining suppliers' strategic roles and how to reengineer processes to optimise operations (Johnson 1999). Internal integration thus facilitates the implementation of strategic changes to improve production and purchasing operations, enhancing the effectiveness of strategic integration with suppliers. Therefore, we propose the following hypothesis.

H6c: Internal integration enhances the effect of strategic integration with suppliers on firm performance.

\subsection{The moderating effect of internal trust}

Information integration enables a firm to acquire knowledge about new materials, machines and technologies from suppliers (Hult, Ketchen Jr., and Slater 2004). Trust between production and purchasing employees can reduce communication barriers between the two departments (Mayer, Davis, and Schoorman 1995). It can facilitate employees to solve problems or disagreements through win-win negotiations, leading to a working environment with reciprocity and solidarity (Adler and Kwon 2002). Trust thus enables purchasing and production staff to work in teams to assimilate and apply the acquired knowledge to improve operations and explore new opportunities, enhancing the value of information integration with suppliers (Yeung et al. 2009). Therefore, we propose the following hypothesis.

H7a: Internal trust enhances the effect of information integration with suppliers on firm performance.

Process integration enhances firm performance by enabling a firm to improve its operations using suppliers' skills and resources. Trust indicates that production and purchasing employees are honest and reliable and guarantees goodwill and benevolence between them (Morgan and Hunt 1994; Mayer, Davis, and Schoorman 1995). Trust also helps production and purchasing employees build close relationships (Zaheer, McEvily, and Perrone 1998; Bunduchi 2013) and develop commitment and loyalty (Adler and Kwon 2002). Employees who trust each other will sublimate their personal interests for collective goals, be more willing to adjust operations and adopt new processes quickly (Bunduchi 2013). A firm can then reengineer and optimise its supply chains using the resources acquired through process integration more effectively and 
efficiently (Gimenez and Venture 2005; Huo 2012). Therefore, we propose the following hypothesis.

H7b: Internal trust enhances the effect of process integration with suppliers on firm performance.

Trust shows that employees in production and purchasing departments have commitment to each other and compatible goals and beliefs (Adler and Kwon 2002). Trust facilitates production and purchasing departments to achieve agreement about suppliers' roles in strategic planning and to implement strategic decisions without formal and costly monitoring (Zaheer, McEvily, and Perrone 1998). A firm can align its long-term strategies with suppliers and swiftly adjust purchasing and production operations according to strategic changes (Swink, Narasimhan, and Wang 2007; Zhao et al. 2011). Trust also plays a prominent role in developing a collective understanding of a firm's competitive objectives and strategies, thereby facilitating production and purchasing departments to effectively develop and implement strategies. Therefore, we propose the following hypothesis.

H7c: Internal trust enhances the effect of strategic integration with suppliers on firm performance.

The research framework and all proposed hypotheses are provided in Figure 1.

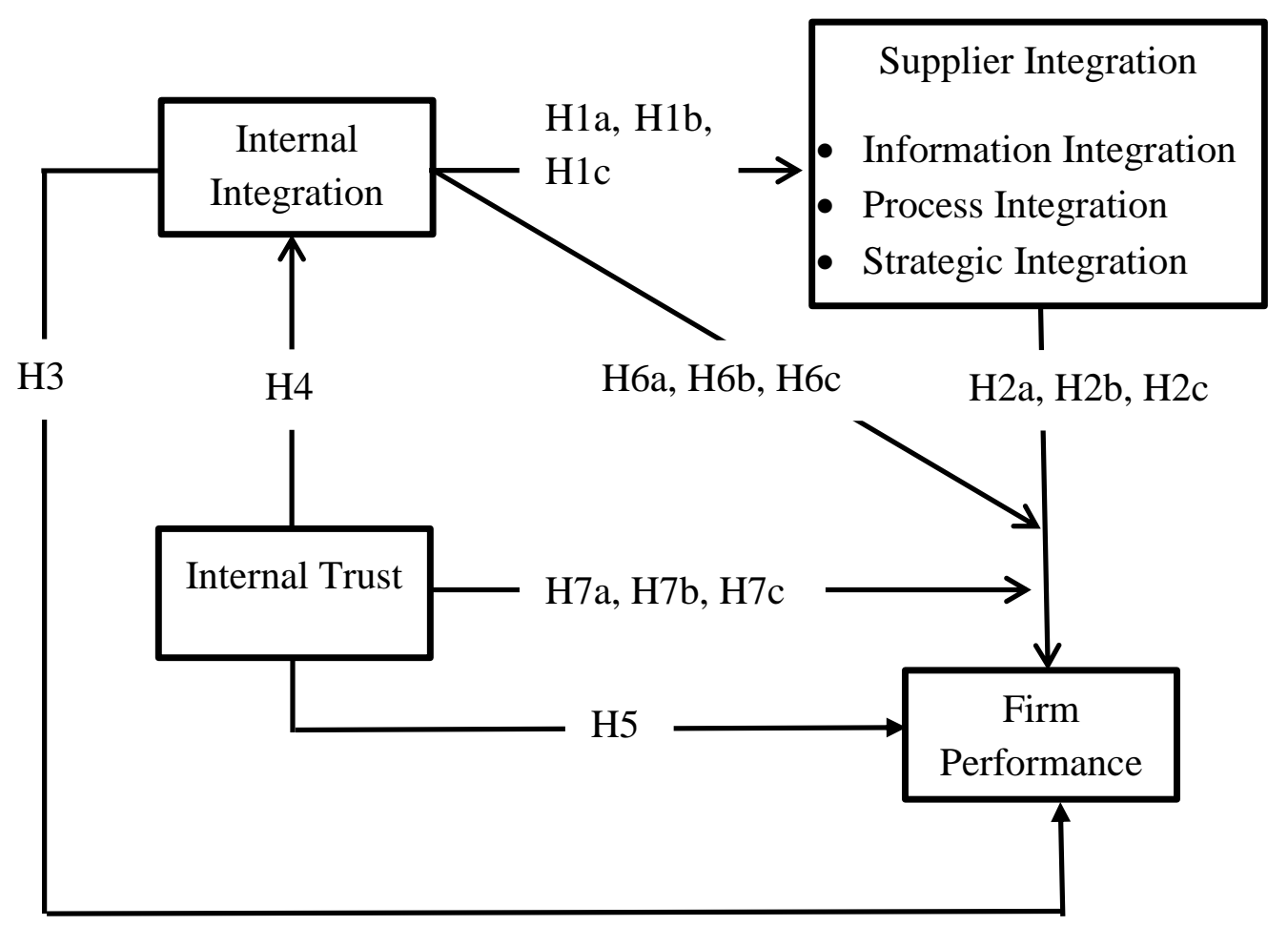

Figure 1. Research framework 


\section{Research method}

\subsection{Questionnaire design}

Based on the relevant literature and the research framework, a survey instrument was designed to measure a manufacturing firm's integration and trust between production and purchasing departments, information, process and strategic integration with suppliers and performance. The questionnaire also elicited the firm's demographic profile, including information related to its industry sector, ownership and size. A multiple-item, 7-point Likert-type scale ( $1=$ 'strongly disagree'; 7= 'strongly agree') was used for all constructs. The scales, which consist of 27 measurement items, are listed in the appendix.

Internal integration was measured using five items related to information sharing, goal alignment and joint decision making between purchasing and production departments. These were developed based on the studies by Stank, Daugherty, and Ellinger (1999) and Paulraj and Chen (2007). Four items related to the goodwill between purchasing and production employees were used to measure internal trust. These were adapted from McAllister (1995) and Le Meunier-FitzHugh and Piercy (2007). Firm performance was measured using market share, sales, return on investment, return on sales and competitiveness ( $\mathrm{Li}$ et al. 2006).

Information integration was operationalised using five items for information sharing and communications between a firm and suppliers (Paulraj and Chen 2007). Process integration was measured with four items on involving suppliers in internal operations and joint decision making with suppliers, which were adapted from Paulraj and Chen (2007). Four items on involving suppliers in strategic planning processes were used to gauge strategic integration with suppliers (Johnson 1999).

Industry sector was included as a control variable in the analysis as the available technologies, clockspeed and competition intensity in an industry may affect managers' decisions on supply management, the effectiveness of supplier integration and profit margins (Zhao et al. 2011). Large firms are more likely to have higher capabilities and better performance than small firms due to their additional resources (Lai et al. 2012). Hence, we also controlled for firm size, which was measured by the number of employees.

An English version of the questionnaire was developed based on the literature and this was subsequently translated into Vietnamese to facilitate the data collection in 
Vietnam. The Vietnamese questionnaire was then translated back into English by six $\mathrm{PhD}$ students studying in the United Kingdom, U.S.A. and Australia. This translated English version was then checked against the original English version for any discrepancies by two researchers and adjustments were made to reflect the original meanings of the questions in English. This back-translation method was used to assure equivalence of the measures in English and Vietnamese and to avoid linguistic bias. The questionnaire was pilot tested using a sample of 15 purchasing and 15 production managers. The researchers discussed the questions with these managers after they had completed the questionnaire and the meanings of the questions were clarified. When any confusion arose, the wording of the questions was modified.

\subsection{Sampling and data collection}

To test the proposed research model, manufacturing firms were randomly selected from Hanoi, Vietnam. A list provided by the Ministry of Plan and Investment was used as the sampling frame for selecting manufacturing firms. The research team randomly selected 320 manufacturing firms from the sampling frame and the questionnaires were delivered to them in person by the statistics department of the Ministry of Plan and Investment. Two informants in each firm (i.e. one production manager and one purchasing manager) were asked to answer the questions about supplier integration, internal integration, internal trust and firm performance. After 8 weeks, the staff of the statistics department collected questionnaires from 192 firms in person. The research team also reminded the participants who had not completed the questionnaire yet. One month later, a further 81 questionnaires were collected by the researchers, leading to a total of 273 questionnaires, giving a response rate of $85.3 \%$. Early and late responses on demographic characteristics, including industry, ownership and number of employees were compared with the t-statistics showing no significant differences, indicating that non-response bias does not appear to be a major concern in this study. Twelve cases were excluded because of missing values. The unit of analysis in this study is the firm, and hence only the average for each scale across the production and purchasing questionnaires was used in subsequent analyses. Detailed information on the sample demographics is shown in Table 1.

Table 1. Firm profiles

\begin{tabular}{|l|l|l|l|l|l|}
\hline Industry & $\begin{array}{l}\text { Number of } \\
\text { firms } \\
\text { (percentage) }\end{array}$ & $\begin{array}{l}\text { Number of } \\
\text { employees }\end{array}$ & $\begin{array}{l}\text { Number of } \\
\text { firms } \\
\text { (percentage) }\end{array}$ & Ownership & $\begin{array}{l}\text { Number of } \\
\text { firms } \\
\text { (percentage) }\end{array}$ \\
\hline
\end{tabular}




\begin{tabular}{|l|c|l|c|l|c|}
\hline $\begin{array}{l}\text { Textile and } \\
\text { garment }\end{array}$ & $97(37.16)$ & $<=200$ & $87(33.33)$ & State-owned & $62(23.75)$ \\
\hline Food & $87(33.33)$ & $201-1000$ & $86(32.95)$ & $\begin{array}{l}\text { Privately- } \\
\text { owned }\end{array}$ & $68(26.05)$ \\
\hline Others & $77(29.51)$ & $>=1001$ & $88(33.72)$ & Joint-venture & $64(24.52)$ \\
\hline Total & $261(100)$ & Total & $261(100)$ & $\begin{array}{l}\text { Foreign- } \\
\text { owned }\end{array}$ & $67(25.67)$ \\
\cline { 4 - 6 } & & & Total & $261(100)$ \\
\hline
\end{tabular}

We used a multiple-informant approach in this study, which helps to avoid the problems caused by common method bias. In addition, we conducted Harman's single factor test by including all items in one principal component analysis (Podsakoff et al. 2003). There is no evidence of common method bias as six distinct factors with eigenvalues above or near 1.0 emerged and no one factor accounted for most of the total variance.

\section{Results of statistical analysis}

Partial least squares (PLS) is chosen for the data analyses because of the sample size and the complexity of the research model (Chin 2010). PLS is a structural equation modelling technique that simultaneously assesses the quality of research constructs (i.e. measurement model) and the relationships between these constructs (i.e. structural model) (Henseler, Ringle, and Sinkovics 2009; Hair et al. 2013). SmartPLS 2.0 M3 is used to assess the measurement and structural models. A bootstrapping estimation procedure is applied, in which 500 random samples of observations with replacements are generated from the original dataset, to examine the significance of the factor loadings in the measurement model and that of the path coefficients in the structural model (Chin 1998).

\subsection{Measurement model}

A confirmatory factor analysis (CFA) is conducted using PLS (Chin 2010). The CFA results are then used to analyse the reliability, convergent validity and discriminant validity of the multiple-item scales. Reliability is assessed in terms of composite reliability and Cronbach's alpha. In the measurement model, the composite reliabilities range from 0.883 to 0.914 and the Cronbach's alpha ranges from 0.836 to 0.874 (appendix), which are all above the recommended threshold value of 0.70 , suggesting adequate reliability. 
We assess convergent validity in terms of the average variance extracted (AVE) (Chin 2010). The results show that all of the AVE values are above the recommended value of 0.50 (ranging from 0.601 to 0.725 ), demonstrating adequate convergent validity. In addition, all item loadings are greater than 0.7 and the smallest t-statistic of the factor loadings is 15.732 , which is significant at the $p<0.001$ level, also suggesting adequate convergent validity (Henseler, Ringle, and Sinkovics 2009).

Discriminant validity is assessed by comparing the square roots of the AVE of each construct with the correlations between the focal construct and every other construct, with a square root higher than the correlation with other constructs suggesting discriminant validity (Henseler, Ringle, and Sinkovics 2009). A comparison of all correlations and square roots of the AVEs indicates adequate discriminant validity for all constructs (Table 2). In addition, the loading of each indicator is greater than all of its cross-loadings, which also indicates discriminant validity on the indicator level (Chin 1998).

Table 2. Correlations, means and standard deviations

\begin{tabular}{|l|l|l|l|l|l|l|}
\hline & $\mathrm{X} 1$ & $\mathrm{X} 2$ & $\mathrm{X} 3$ & $\mathrm{X} 4$ & $\mathrm{X} 5$ & $\mathrm{X} 6$ \\
\hline Information integration (X1) & $\mathbf{0 . 8 0 4}^{\mathrm{a}}$ & & & & & \\
\hline Process integration (X2) & $0.318^{* *}$ & $\mathbf{0 . 8 5 1}$ & & & & \\
\hline Strategic integration (X3) & $0.361^{* *}$ & $0.497^{* *}$ & $\mathbf{0 . 8 5 1}$ & & & \\
\hline Internal integration (X4) & $0.345^{* *}$ & $0.415^{* *}$ & $0.410^{* *}$ & $\mathbf{0 . 7 7 5}$ & & \\
\hline Internal trust (X5) & $0.388^{* *}$ & $0.508^{* *}$ & $0.524^{* *}$ & $0.674^{* *}$ & $\mathbf{0 . 8 3 2}$ & \\
\hline Firm performance (X6) & $0.419^{* *}$ & $0.504^{* *}$ & $0.467^{* *}$ & $0.383^{* *}$ & $0.529^{* *}$ & $\mathbf{0 . 7 7 7}$ \\
\hline Mean & 3.927 & 3.953 & 3.921 & 3.926 & 4.069 & 4.036 \\
\hline Standard deviation & 0.893 & 0.933 & 0.932 & 0.882 & 0.971 & 0.830 \\
\hline
\end{tabular}

Notes: ${ }^{a}$ The square root of the average variance extracted (AVE) is shown on the diagonal of the matrix in bold. The interconstruct correlation is shown off the diagonal. ${ }^{* *} p<0.05$ level

\subsection{Structural model}

PLS is also used to examine the structural models. We first test the basic model, which includes the impact of internal trust on internal integration, the impact of internal integration on supplier integration and the direct effects of internal integration, internal trust, supplier integration and control variables on firm performance. The results are reported in Table 3. This model explains $41.3 \%$ of the firm performance variance $\left(R^{2}\right)$, indicating that the model has adequate explanatory power (Chin 1998). The results show that the effects of the industry and firm size on firm performance are not significant. We find that internal integration enhances information $(b=0.361, \mathrm{p}<0.001)$, process $(b=0.429, \mathrm{p}<0.001)$ and strategic integration $(b=0.436, \mathrm{p}<0.001)$ with suppliers, supporting H1a, H1b and H1c. Information $(b=0.199, \mathrm{p}<0.001)$, process $(b=0.247$, 
$\mathrm{p}<0.001)$ and strategic integration $(b=0.137, \mathrm{p}<0.05)$ with suppliers all have significant effects on firm performance, providing support for $\mathrm{H} 2 \mathrm{a}, \mathrm{H} 2 \mathrm{~b}$ and $\mathrm{H} 2 \mathrm{c}$. The results also show that internal trust improves internal integration $(b=0.708, \mathrm{p}<0.001)$ and internal integration has a significant impact on firm performance $(b=0.282, \mathrm{p}<0.001)$. However, the direct effect of internal trust on firm performance is not significant. Therefore, $\mathrm{H} 3$ and $\mathrm{H} 4$ are supported, but $\mathrm{H} 5$ is not.

Table 3. Results of the basic model

\begin{tabular}{|l|l|l|l|}
\hline Path & $\begin{array}{l}\text { Coefficient } \\
\text { (standard error) }\end{array}$ & $\begin{array}{l}\mathbf{T} \text { value } \\
\text { value) }\end{array}$ & $\begin{array}{l}\text { Confidence interval } \\
(\mathbf{9 5 \% )}\end{array}$ \\
\hline $\begin{array}{l}\text { Internal integration } \rightarrow \\
\text { Information integration }\end{array}$ & $0.361(0.055)$ & $\begin{array}{l}6.512 \\
(\mathrm{p}<0.001)\end{array}$ & $(0.2530 .469)$ \\
\hline $\begin{array}{l}\text { Internal integration } \rightarrow \text { Process } \\
\text { integration }\end{array}$ & $0.429(0.053)$ & $\begin{array}{l}8.093 \\
(\mathrm{p}<0.001)\end{array}$ & $(0.3520 .533)$ \\
\hline $\begin{array}{l}\text { Internal integration } \rightarrow \\
\text { Strategic integration }\end{array}$ & $0.436(0.055)$ & $\begin{array}{l}7.919 \\
(\mathrm{p}<0.001)\end{array}$ & $(0.3280 .544)$ \\
\hline $\begin{array}{l}\text { Information integration } \rightarrow \\
\text { Firm performance }\end{array}$ & $0.199(0.052)$ & $\begin{array}{l}3.834 \\
(\mathrm{p}<0.001)\end{array}$ & $(0.0970 .300)$ \\
\hline $\begin{array}{l}\text { Process integration } \rightarrow \text { Firm } \\
\text { performance }\end{array}$ & $0.247(0.069)$ & $\begin{array}{l}3.582 \\
(\mathrm{p}<0.001)\end{array}$ & $(0.1120 .382)$ \\
\hline $\begin{array}{l}\text { Strategic integration } \rightarrow \text { Firm } \\
\text { performance }\end{array}$ & $0.137(0.058)$ & $\begin{array}{l}2.360 \\
(\mathrm{p}<0.05)\end{array}$ & $(0.0230 .251)$ \\
\hline $\begin{array}{l}\text { Internal integration } \rightarrow \text { Firm } \\
\text { performance }\end{array}$ & $0.282(0.079)$ & $\begin{array}{l}3.558 \\
(\mathrm{p}<0.001)\end{array}$ & $(0.1270 .437)$ \\
\hline $\begin{array}{l}\text { Internal trust } \rightarrow \text { Internal } \\
\text { integration }\end{array}$ & $0.708(0.029)$ & $\begin{array}{l}24.807 \\
(\mathrm{p}<0.001)\end{array}$ & $(0.6510 .765)$ \\
\hline $\begin{array}{l}\text { Internal trust } \rightarrow \text { Firm } \\
\text { performance }\end{array}$ & $-0.028(0.043)$ & $\begin{array}{l}0.656 \\
(\mathrm{p}>0.1)\end{array}$ & $(-0.1120 .056)$ \\
\hline $\begin{array}{l}\text { Firm size } \rightarrow \\
\text { performance Firm }\end{array}$ & $-0.033(0.031)$ & $\begin{array}{l}1.071 \\
(\mathrm{p}>0.1)\end{array}$ & $(-0.0930 .028)$ \\
\hline Industry $\rightarrow$ Firm performance & $-0.036(0.043)$ & $0.846(\mathrm{p}>0.1)$ & $(-0.1200 .048)$ \\
\hline $\begin{array}{l}\mathbf{R}^{2} \\
\text { Firm performance }(41.3 \%) ; \text { Information integration }(13.0 \%) ; \text { Process integration } \\
(18.4 \%) ; \text { Strategic integration }(19.0 \%) ; \text { Internal integration }(50.1 \%)\end{array}$ \\
\hline
\end{tabular}

Then, the interaction terms are created and added to the basic model to test the moderating effects of internal integration and trust on the impacts of information, process and strategic integration with suppliers on firm performance. The results are reported in Table 4. We have applied the product indicator approach which involves multiplying each mean-centred indicator of the exogenous latent variables (i.e. information, process and strategic integration) with each indicator of the moderator variables (i.e. internal integration and trust) (Hair et al. 2013). These product indicators become the indicators of the interaction terms. Following the method suggested by Hair et al. (2013), we calculate variance inflation factors (VIFs) to assess multicollinearity among explanatory variables of firm performance in the basic, internal 
integration moderation and internal trust moderation models. The VIF values range from 1.218 to 2.324 , which are well below the benchmark of 5, suggesting multicollinearity is not a concern in this study (Hair et al. 2013). We find that the internal integration moderation model explains $43.7 \%$ of the firm performance variance. Internal integration enhances the impact of process integration on firm performance $(b=0.120, \mathrm{p}<0.05)$, but it does not significantly influence the effects of information and strategic integration on firm performance. Hence, H6b is supported, but H6a and H6c are not. We also find that the internal trust moderation model explains $45.7 \%$ of the firm performance variance. Internal trust enhances the effect of process integration on firm performance $(b=0.183, \mathrm{p}<0.05)$, but reduces the impact of strategic integration on firm performance $(b=-0.166, \mathrm{p}<0.05)$, and it does not significantly moderate the effect of information integration on firm performance. Hence, $\mathrm{H} 7 \mathrm{~b}$ is supported, but $\mathrm{H} 7 \mathrm{a}$ and $\mathrm{H} 7 \mathrm{c}$ are not.

Table 4. Results of the moderation analysis

\begin{tabular}{|c|c|c|c|}
\hline Path & $\begin{array}{l}\text { Coefficient } \\
\text { (standard error) }\end{array}$ & $\begin{array}{l}\text { T value (p } \\
\text { value) }\end{array}$ & $\begin{array}{l}\text { Confidence } \\
\text { interval }(95 \%)\end{array}$ \\
\hline \multicolumn{4}{|c|}{ Internal integration moderation model } \\
\hline $\begin{array}{l}\text { Internal integration } \times \\
\text { Information integration } \rightarrow \\
\text { Firm performance }\end{array}$ & $-0.098(0.092)$ & $\begin{array}{l}1.085 \\
(\mathrm{p}>0.1)\end{array}$ & $(-0.2780 .082)$ \\
\hline $\begin{array}{l}\text { Internal integration } \times \text { Process } \\
\text { integration } \rightarrow \text { Firm } \\
\text { performance }\end{array}$ & $0.120(0.059)$ & $\begin{array}{l}2.045 \\
(\mathrm{p}<0.05)\end{array}$ & $(0.0040 .236)$ \\
\hline $\begin{array}{l}\text { Internal integration } \times \text { Strategic } \\
\text { integration } \rightarrow \text { Firm } \\
\text { performance }\end{array}$ & $0.007(0.044)$ & $\begin{array}{l}0.170 \\
(p>0.1)\end{array}$ & $(-0.0790 .093)$ \\
\hline $\mathbf{R}^{2}$ & \multicolumn{3}{|c|}{ Firm performance $(43.7 \%)$} \\
\hline \multicolumn{4}{|l|}{ Internal trust moderation model } \\
\hline $\begin{array}{l}\text { Internal trust } \times \text { Information } \\
\text { integration } \rightarrow \text { Firm } \\
\text { performance }\end{array}$ & $-0.085(0.060)$ & $\begin{array}{l}1.414 \\
(p>0.1)\end{array}$ & $(-0.2030 .033)$ \\
\hline $\begin{array}{l}\text { Internal trust } \times \text { Process } \\
\text { integration } \rightarrow \text { Firm } \\
\text { performance }\end{array}$ & $0.183(0.076)$ & $\begin{array}{l}2.417 \\
(\mathrm{p}<0.05)\end{array}$ & $(0.0340 .332)$ \\
\hline $\begin{array}{l}\text { Internal trust } \times \text { Strategic } \\
\text { integration } \rightarrow \text { Firm } \\
\text { performance }\end{array}$ & $-0.166(0.069)$ & $\begin{array}{l}2.422 \\
(\mathrm{p}<0.05)\end{array}$ & $(-0.301-0.031)$ \\
\hline $\mathbf{R}^{2}$ & \multicolumn{3}{|c|}{ Firm performance $(45.7 \%)$} \\
\hline
\end{tabular}

\section{Discussion}

The findings show that internal integration and trust do not influence the effect of information integration on firm performance. Vietnam's cultural environment provides a possible explanation for the results. Vietnam's culture is characterized by high power 
distance (Hofstede, Hofstede, and Minkov 2010), which hinders communications and openness. Employees at low hierarchical levels are not able to make independent decisions. Internal integration and trust enable employees in production and purchasing departments to work in teams to analyse, interpret, create and share knowledge, enhancing information integration's impact (Hult, Ketchen Jr., and Slater 2004). In a high power distance culture, employees are neither encouraged to make decisions and take responsibility for the outcomes, nor empowered to create new knowledge by applying the information acquired from suppliers. Hence, the moderating effects of internal integration and trust are not significant.

We also find that the positive influence of strategic integration on firm performance is not affected by internal integration. A firm's decisions about long-term strategies and suppliers' roles in strategic planning are usually made at the firm level and by top management. Although internal integration enables a firm to develop coordinated and connected processes, which are critical to the implementation of strategies, employees in purchasing and production departments may not directly participate in strategic decision making. Hence, the moderating effect of internal integration is not significant.

The results show that internal trust does not directly affect firm performance and that the impact of strategic integration on firm performance is reduced by internal trust. Researchers argue that trust among employees can have harmful effects (Adler and Kwon 2002; Villena, Revilla, and Choi 2011). Too much trust may lead to undesired rigidities, inertia and relational lock-in between employees and they may be reluctant to respond to strategic changes and adjust production and purchasing operations accordingly (Adler and Kwon 2002). Due to overconfidence with colleagues, employees may lose flexibility and objectivity in decision making and become blind to the changes in strategies (Wang, Zhang, and Li 2017). Hence, trust attenuates the positive impact of strategic integration on firm performance. In addition, establishing and maintaining internal trust requires considerable investments in relationships between employees which may not be cost efficient in certain situations (Adler and Kwon 2002). Trust may lead to unnecessary obligations that constrain decision making and create occasions for opportunistic behaviour among employees (Villena, Revilla, and Choi 2011). Hence, internal trust has both positive and negative impacts, leading to an insignificant direct effect on firm performance. We estimate the indirect effect of internal trust on firm performance through internal integration by multiplying the path coefficient from internal trust to internal integration and that from internal integration 
to firm performance. The indirect effect is $0.708 \times 0.282=0.200$. Sobel's $Z$ test is then applied to assess the significance of the indirect effect and the result indicates that it is significant at $\mathrm{p}<0.001$ level. Therefore, internal integration mediates the impact of internal trust on firm performance.

\section{Conclusions}

This study aims to investigate the impacts of information, process and strategic integration with suppliers on firm performance. The findings provide a possible explanation for the inconsistent results on the relationship between supplier integration and performance outcomes. Data collected from 261 Vietnamese manufacturers are used to empirically test a model of the direct effects of the three types of supplier integration on firm performance and how they are influenced by internal integration and trust.

\subsection{Theoretical contributions}

This study contributes to the operations management literature in two ways. First, the results reveal that the relationship between supplier integration and firm performance is contingent on internal integration. Existing studies report inconclusive results on the interaction effect of internal and supplier integration on firm performance (Flynn, Huo, and Zhao 2010; Schoenherr and Swink 2012). This study reveals that this is because internal integration plays different roles in moderating the effects of information, process and strategic integration with suppliers. In addition, the results show that both internal and supplier integration enhance firm performance and internal integration positively associates with the three types of supplier integration. These findings help researchers understand why manufacturers with the highest levels of internal and supplier integration can achieve the best performance (Frohlich and Westbrook 2001; Flynn, Huo, and Zhao 2010; Schoenherr and Swink 2012). They also extend current understandings of the mechanisms through which internal and supplier integration jointly contribute to firm performance. This study discovers that complementarities can be achieved through the interactions of internal and supplier integration and finds that firms are unable to reap the full benefits of their supplier integration efforts without internal integration. We thus suggest that researchers take a contingent view of supplier integration and explicitly consider the interrelationships between internal and supplier integration when investigating the performance outcomes of supplier integration. 
Second, this study provides empirical evidence that the relationship between supplier integration and firm performance is moderated by the trust among employees. The findings enhance current understandings on the contingencies that influence the effect of supplier integration (Wong, Boon-itt, and Wong 2011; Lai et al. 2012; Huo et al. 2014). We find that internal trust has insignificant, positive and negative influences on the effects of information, process and strategic integration with suppliers on firm performance, respectively. This study thus reveals that internal trust is one of the reasons for the mixed findings on the impact of supplier integration on performance. The findings also provide empirical evidence that a universal perspective on supplier integration may lead to an incomplete or a biased understanding of its impact on firm performance. We suggest researchers examine the performance outcomes of the different types of supplier integration individually. In addition, we find that internal trust increases firm performance indirectly through internal integration. The results provide empirical evidence on the joint effects of internal integration and trust, and enhance current understandings on the mechanisms through which internal trust contributes to firm performance. Therefore, this study links trust with internal and supplier integration and elucidates their complex relationships. The results also reveal that trust is a double-edged sword that has both positive and negative aspects for supplier integration (Mayer, Davis, and Schoorman 1995; Adler and Kwon 2002; Villena, Revilla, and Choi 2011).

\subsection{Managerial implications}

This study also provides managerial guidelines on how to implement supplier integration to improve firm performance. We suggest managers take a balanced view and emphasise both internal and supplier integration when designing purchasing and production systems. Network-based information systems (e.g. enterprise resource planning) and standard operating procedures guiding inter- and intra-organisational interactions should be applied in purchasing and production systems. Cross-functional teams and meetings can be used for production planning and supply management. Managers can also invest in training programs to make employees aware of their responsibilities and the firm's strategies and competitive goals. When developing a firm's strategies, managers must not only consider suppliers' roles, but also allow them to participate in strategic planning processes. In addition, a contingent perspective must be taken to fully gain the benefits of supplier integration. Managers must be aware that internal integration and trust do not enhance the effects of information and strategic 
integration on firm performance. If a firm emphasises process integration with suppliers, we suggest managers create procedures that enable employees to build inter-personal relationships. Managers can adopt advanced information technologies and organise regular meetings to facilitate internal information sharing and joint decision making at the same time. These practices also enable the firm to capture the benefits of the investments in internal relationships.

\subsection{Limitations and future research directions}

While this study makes significant contributions to the academic literature and managerial practices, it nonetheless has limitations that open avenues for future research. First, this study only focuses on the integration and trust between production and purchasing departments. Future studies can examine the effects of intraorganisational integration and trust that relate to all main functions (e.g. production, purchasing, marketing, research and development and logistics) on inter-organisational integration. Second, information, process and strategic integration with suppliers are not independent. Future studies can examine their complementary effects on firm performance. Third, this study only focuses on a firm's market and financial performance. Exploring how supplier integration affects a firm's social and sustainability goals is an interesting research topic. Fourth, researchers argue that trust has both bright and dark sides and different types of trust (e.g. goodwill and competence trust) may affect firm performance in different ways. A holistic investigation on the relationships between trust and firm performance is another interesting topic. Fifth, this study only collects data from manufacturers. Future studies can survey both manufacturers and suppliers to capture the dyadic relationships and investigate the impact of supplier integration. Sixth, although this study provides some interesting findings on the moderating effects of internal integration and trust on the relationships between supplier integration and firm performance in Vietnam, we cannot ascertain whether these relationships are the same in other countries. Useful extensions can be examining the research model in other countries with different cultural and business environments and explicitly investigating the impacts of cultural dimensions on supplier integration.

\section{References}

Adler, P.S., and S. Kwon. 2002. "Social capital: Prospects for a new concept." Academy of Management Review 27 (1):17-40. 
Alfalla-Luque, R., C. Medina-Lopez, and P.K. Dey. 2013. "Supply chain integration framework using literature review." Production Planning \& Control 24 (8/9):800-17.

Alfalla-Luque, R., C. Medina-Lopez, and H. Schrage. 2013. "A study of supply chain integration in the aeronautics sector." Production Planning \& Control 24 (8/9):769-84.

Bunduchi, R. 2013. "Trust, partner selection and innovation outcome in collaborative new product development." Production Planning \& Control 24 (2/3):145-57.

Cai, S., M. Jun, and Z. Yang. 2010. "Implementing supply chain information integration in China: The role of institutional forces and trust." Journal of Operations Management 28 (3):257-68.

Chen, D., G., Doumeingts, and Vernadat, F. 2008. "Architectures for enterprise integration and interoperability: Past, present and future." Computers in Industry 59(7):647-59.

Chin, W.W. 1998. "The Partial Least Squares approach to structural equation modeling." In Modern Methods for Business Research, edited by G.A. Marcoulides, 295-336. Mahwah, NJ.: Lawrence Brlbaum Associates.

— 2010. "How to write up and report PLS analyses." In Handbook of Partial Least Squares: Concepts, methods and applications, edited by V.E. Vinzi, W.W. Chin, J. Henseler and H. Wang. Berlin: Springer.

Dröge, C., J. Jayaram, and S. Vickery. 2004. "The effects of internal versus external integration practices on time-based performance and overall firm performance." Journal of Operations Management 22 (6):557-73.

Flynn, B.B., B. Huo, and X. Zhao. 2010. "The impact of supply chain integration on performance: A contingency and configuration approach." Journal of Operations Management 28 (1):58-71.

Frohlich, M.T., and R. Westbrook. 2001. "Arcs of integration: an international study of supply chain strategies." Journal of Operations Management 19 (2):185-200.

Germain, R., and K.N.S. Iyer. 2006. "The interaction of internal and downstream integration and its association with performance." Journal of Business Logistics $27(2): 29-52$.

Gimenez, C., and E. Venture. 2005. "Logistics-production, logistics-marketing and external integration: Their impact on performance." International Journal of Operations and Production Management 21 (5):20-38. 
Hair, J. F., G.T.M. Hult, C.M. Ringle, and M. Sarstedt. 2013. A primer on Partial Least Squares Structural Equation Modeling (PLS-SEM). Los Angeles: SAGE Publications, Inc.

Henseler, J., C.M. Ringle, and R.R. Sinkovics. 2009. "The use of partial least squares path modeling in international marketing." In Advances in International Marketing, edited by R.R. Sinkovics and P.N. Ghauri, 277-319. Bingley: Emerald.

Hofstede, G., G.J. Hofstede, and M. Minkov. 2010. Cultures and organizations: Software of the mind: Intercutural cooperation and its importance for survival. New York: McGraw-Hill.

Hult, G.T.M., D.J. Ketchen Jr., and S.F. Slater. 2004. "Information processing, knowledge development, and strategic supply chain performance." Academy of Management Journal 47 (2):241-53.

Huo, B. 2012. "The impact of supply chain integration on company performance: an organizational capability perspective." Supply Chain Management: An International Journal 17 (6):596-610.

Huo, B., Y. Qi, Z. Wang, and X. Zhao. 2014. "The impact of supply chain integration on firm performance: The moderating role of competitive strategy." Supply Chain Management: An International Journal 19 (4):369-84.

Johnson, J.L. 1999. "Strategic integration in industrial distribution channels: Managing the interfirm relationship as a strategic asset." Journal of the Academy of Marketing Science 27 (1):4-18.

Kumar, S., J. Medina, and M. T. Nelson. 2009. "Is the offshore outsourcing landscape for us manufacturers migrating away from China?" Supply Chain Management: An International Journal 14 (5):342-8.

Lai, F., M. Zhang, D.M.S. Lee, and X. Zhao. 2012. "The impact of supply chain integration on mass customization capability: An extended resource-based view." IEEE Transactions on Engineering Management 59 (3):443-56.

Le Meunier-FitzHugh, K., and N.F. Piercy. 2007. "Does collaboration between sales and marketing affect business performance?" Journal of Personal Selling and Sales Management 27 (3):207-20.

Li, S., B. Ragu-Nathan, T.S. Ragu-Nathan, and S.S. Rao. 2006. "The impact of supply chain management practices on competitive advantage and organizational performance." Omega 34 (2):107-24. 
Mayer, R.C., J.H. Davis, and F.D. Schoorman. 1995. "An integrative model of organizational trust." Academy of Management Review 20 (3):709-34.

McAllister, D. J. 1995. "Affect- and cognition- based trust as foundations for interpersonal cooperation in organizations." Academy of Management Journal 38 (1):24-59.

Morgan, R.M., and S.D. Hunt. 1994. "The commitment-trust theory of relationship marketing." Journal of Marketing 58 (3):20-38.

Moyano-Fuentes, J., M. Sacristán-Díaz, and P. Garrido-Vega. 2016. "Improving supply chain responsiveness through Advanced Manufacturing Technology: The mediating role of internal and external integration." Production Planning \& Control 27(9):686-97.

Narasimhan, R., and S.W. Kim. 2002. "Effect of supply chain integration on the relationship between diversification and performance: Evidence from Japanese and Korean firms." Journal of Operations Management 20 (3):303-23.

Palomero, S., and R. Chalmeta. 2014. "A guide for supply chain integration in SMEs." Production Planning \& Control 25 (5):372-400.

Panetto, H., and A. Molina. 2008. "Enterprise integration and interoperability in manufacturing systems:Trends and issues". Computers in Industry 59(7):641-6.

Paulraj, A., and I.J. Chen. 2007. "Strategic buyer-supplier relationship, information technology and external logistics integration." Journal of Supply Chain Management 43 (2):2-14.

Podsakoff, P.M., S.B. MacKenzie, J.Y. Lee, and N.P. Podsakoff. 2003. "Common method biases in behavioral research: A critical review of the literature and recommended remedies." Journal of Applied Psychology 88 (5):879-903.

Schoenherr, T., and M. Swink. 2012. "Revisiting the arcs of integration: Crossvalidations and extensions." Journal of Operations Management 30 (1/2):99115.

Stank, T.P., P.J. Daugherty, and A.E. Ellinger. 1999. "Marketing/logistics integration and firm performance." The International Journal of Logistics Management 10 (1):11-24.

Swink, M., R. Narasimhan, and C. Wang. 2007. "Managing beyond the factory walls: Effects of four types of strategic integration on manufacturing plant performance." Journal of Operations Management 25 (1):148-64. 
"The Flying Factory". The Economist, Nov 13th 2014, https://www.economist.com/news/special-report/21631799-asia-has-builtweb-economic-interdependence-which-china-would-be-ill-advised

Villena, V.H., E. Revilla, and T.Y. Choi. 2011. "The dark side of buyer-supplier relationships: A social capital perspective." Journal of Operations Management 29 (6):561-76.

Wang, L., J.H.Y. Yeung, and M. Zhang. 2011. "The impact of trust and contract on innovation performance: The moderating role of environmental uncertainty." International Journal of Production Economics 134 (1):114-22.

Wang, L., M. Zhang, and X. Li. 2017. "Trust and knowledge creation: The moderating effects of legal inadequacy." Industrial Management \& Data Systems 117(10):2194-209.

Williams, B.D., J. Roh, T. Tokar, and M. Swink. 2013. "Leveraging supply chain visibility for responsiveness: The moderating role of internal integration." Journal of Operations Management 31 (7/8):543-54.

Wong, C.Y., S. Boon-itt, and C.W.Y. Wong. 2011. "The contingency effects of environmental uncertainty on the relationship between supply chain integration and operational performance." Journal of Operations Management 29 (6):60415 .

Yeung, J.H.Y., W. Selen, M. Zhang, and B. Huo. 2009. "The effects of trust and coercive power on supplier integration." International Journal of Production Economics 120 (1):66-78.

Yu, W. 2015. "The effect of IT-enabled supply chain integration on performance." Production Planning \& Control 26 (12):945-57.

Zaheer, A., B. McEvily, and V. Perrone. 1998. "Does trust matter? Exploring the effects of interorganizational and interpersonal trust on performance." Organization Science 9 (2):141-59.

Zhang, M., and B. Huo. 2013. "The impact of dependence and trust on supply chain integration." International Journal of Physical Distribution \& Logistics Management 43 (7):544-63.

Zhao, L., B. Huo, L. Sun, and X. Zhao. 2013. "The impact of supply chain risk on supply chain integration and company performance: A global investigation." Supply Chain Management: An International Journal 18 (2):115-31. 
Zhao, X., B. Huo, B.B. Flynn, and J.H.Y. Yeung. 2008. "The impact of power and relationship commitment on the integration between manufacturers and customers in a supply chain." Journal of Operations Management 26 (3):36888.

Zhao, X., B. Huo, W. Selen, and J.H.Y. Yeung. 2011. "The impact of internal integration and relationship commitment on external integration." Journal of Operations Management 29 (1/2):17-32.

Appendix 1. Measurement items and reliability and validity assessment

\begin{tabular}{|c|c|}
\hline & Loading $b$ \\
\hline \multicolumn{2}{|l|}{ Information integration C.R. $=0.901$ alpha $=0.863 \mathrm{AVE}=0.646^{\mathrm{a}}$} \\
\hline Our firm and our major suppliers share necessary information. & .850 \\
\hline $\begin{array}{l}\text { Our major suppliers are provided with any information that might help } \\
\text { them. }\end{array}$ & .818 \\
\hline $\begin{array}{l}\text { Our firm and our major suppliers keep each other informed about events } \\
\text { or changes that affect the other company. }\end{array}$ & .862 \\
\hline Our firm and our major suppliers exchange performance feedback. & .712 \\
\hline Our firm often communicates directly with key suppliers. & .768 \\
\hline \multicolumn{2}{|l|}{ Process integration C.R. $=0.913$ alpha $=0.873$ AVE $=0.724$} \\
\hline We involve key suppliers in the product design and development stage. & .871 \\
\hline We have key supplier membership/participation in our project teams. & .834 \\
\hline $\begin{array}{l}\text { Our company involves suppliers in production planning and inventory } \\
\text { management. }\end{array}$ & .829 \\
\hline We involve key suppliers in joint problem solving. & .868 \\
\hline \multicolumn{2}{|l|}{ Strategic integration C.R. $=0.914$ alpha $=0.874$ AVE $=0.725$} \\
\hline $\begin{array}{l}\text { Our firm's long-term strategy depends on maintaining a good, healthy } \\
\text { relationship with our major suppliers. }\end{array}$ & .880 \\
\hline $\begin{array}{l}\text { We consider our major suppliers as a large part of the picture when } \\
\text { developing our firm's strategy. }\end{array}$ & .846 \\
\hline $\begin{array}{l}\text { We involve our key suppliers in developing our business and strategy } \\
\text { planning. }\end{array}$ & .822 \\
\hline $\begin{array}{l}\text { Our firm would immediately have to change our competitive strategy if } \\
\text { our major suppliers went out of business. }\end{array}$ & .857 \\
\hline \multicolumn{2}{|l|}{ Internal integration C.R. $=0.883$ alpha $=0.839 \mathrm{AVE}=0.601$} \\
\hline Production and purchasing staff often share necessary information. & .767 \\
\hline Production and purchasing staff often exchange performance feedback. & .747 \\
\hline Production and purchasing staff often share plans. & .785 \\
\hline Production and purchasing staff achieve goals collectively. & .765 \\
\hline $\begin{array}{l}\text { Production and purchasing staff make joint decisions about ways to } \\
\text { improve efficiency. }\end{array}$ & .810 \\
\hline \multicolumn{2}{|l|}{ Internal trust $\mathrm{C} . \mathrm{R} .=0.899$ alpha $=0.851 \mathrm{AVE}=0.692$} \\
\hline Production and purchasing staff get along well with each other. & .877 \\
\hline $\begin{array}{l}\text { We feel that the production unit are in harmony with those of the } \\
\text { purchasing unit. }\end{array}$ & .890 \\
\hline
\end{tabular}




\begin{tabular}{|l|l|}
\hline $\begin{array}{l}\text { There is little or no conflict between the production staff and the } \\
\text { purchasing staff. }\end{array}$ & .727 \\
\hline $\begin{array}{l}\text { Both production and purchasing staff made considerable emotional } \\
\text { investments in the working relationship. }\end{array}$ & .824 \\
\hline Firm performance C.R. $\mathbf{0 . 8 8 4}$ alpha=0.836 AVE= 0.604 & .814 \\
\hline Our firm has achieved an increase in market share. & .739 \\
\hline Our firm has achieved an increase in sales. & .803 \\
\hline Our firm has achieved an increase in return on investment. & .734 \\
\hline Our firm has achieved an increase in return on sales. & .791 \\
\hline Our firm has achieved an increase in overall competitive position. & \\
\hline
\end{tabular}

Notes: ${ }^{a}$ C.R: composite reliability; alpha: Cronbach's alpha; AVE: average variance extracted. ${ }^{b}$ All item loadings are significant at the $p<0.001$ level. 